\title{
GYNECOLOGIC AND OBSTETRIC PROFILE OF STATE IMPRISONED FEMALES
}

\author{
Samila Gomes Ribeiro ${ }^{1}$, Paula Renata Amorim Lessa², Alana Santos Monte ${ }^{3}$, Elizian Braga Rodrigues \\ Bernardo , Ana Izabel Oliveira Nicolau ${ }^{5}$, Priscila De Souza Aquino ${ }^{6}$, Ana Karina Bezerra Pinheiro
}

\begin{abstract}
${ }^{1}$ Student of the Master's Course of the Nursing Graduate Program at Federal University of Ceará (UFC). Fellow of the Brazilian Federal Agency for Support and Evaluation of Graduate Education (CAPES). Ceará, Brazil. E-mail: samilaribeiro@yahoo. com.br

2 Student of the Master's Course of the Nursing Graduate Program at UFC. CAPES fellow. Ceará, Brazil. E-mail: paularenatal@ yahoo.com.br

${ }^{3}$ Nursing undergraduate at UFC. Fellow of the Tutorial Education Program (PET). Ceará, Brazil. E-mail: alanasmonte@yahoo. com.br

${ }^{4}$ Nursing undergraduate at UFC. PET fellow. Ceará, Brazil. E-mail: elizian_rodrigues@yahoo.com.br

${ }^{5}$ Master in Nursing. Assistant Professor at the Federal University of Piauí. E-mail: anabelpet@yahoo.com.br

${ }^{6}$ Ph.D. in Nursing. CAPES fellow (post-doctoral). Ceará, Brazil. E-mail: priscilapetenf@yahoo.com.br

${ }^{7}$ Ph.D. in Nursing. Adjunct Professor IV at UFC. CNPq researcher. Ceará, Brazil E-mail: anakarinaufc@hotmail.com
\end{abstract}

\begin{abstract}
The objective of this study was to identify the gynecologic and obstetric profile of imprisoned females in the State of Ceará. This is a documental retrospective study with a quantitative approach, performed in the Female Prison Institute of the State of Ceará with 672 medical files. Regarding age, $62.3 \%$ of the women were 31 years old. The most prevalent age bracket for menarche was 10 to 13 years, $(57.2 \%)$ and age of first sexual experience was 11 to 15 years $(55.8 \%)$. The most common contraceptive method used was tubal ligation (29.5\%). Homosexual behavior was found in $17.9 \%$ of inmates. Data also demonstrate an elevated number of pregnancies and abortions. In conclusion, these women require more care from health professionals and more specific health interventions in the prison context since they present high gynecologic and obstetrical risks.
\end{abstract}

DESCRIPTORS: Prisons. Population characteristics. Females. Nursing.

\section{PERFIL GINECO-OBSTÉTRICO DE MULHERES ENCARCERADAS NO ESTADO DO CEARÁ}

RESUMO: Objetivou-se identificar o perfil gineco-obstétrico de mulheres encarceradas no Ceará. Estudo documental, retrospectivo, com abordagem quantitativa, realizado no Instituto Penal Feminino do Estado do Ceará, com 672 prontuários. No tocante à idade, $62,3 \%$ das mulheres possuía até 31 anos. A faixa etária da menarca mais prevalente foi de 10 a 13 anos, com $57,2 \%$, e a da coitarca foi de 11 a 15 anos, com $55,8 \%$. O método contraceptivo mais utilizado foi a laqueadura tubária, representada por $29,5 \%$. O comportamento homossexual foi encontrado em $17,9 \%$. Os dados ainda evidenciaram um número elevado de gestações e abortamentos. Conclui-se que essas mulheres necessitam de maior atenção por parte dos profissionais de saúde e de ações de saúde que sejam especificas para o contexto prisional, pois apresentam riscos gineco-obstétricos.

DESCRITORES: Prisões. Características da população. Mulheres. Enfermagem.

\section{PERFIL GINECOLÓGICO Y OBSTÉTRICO DE MUJERES ENCARCELADAS EL ESTADO DE CEARÁ}

RESUMÉN: El objetivo de este estudio fue identificar el perfil ginecológico y obstétrico de mujeres encarceladas en el Ceará. Estudio documental, retrospectivo con enfoque cuantitativo, realizado en el Instituto Penal de Mujer del Estado del Ceará, con 672 registros. Respecto a la edad, $62,3 \%$ de las mujeres había hasta 31 años. La edad de la menarquía fue más prevalente 10 a 13 años, con 57,2\%, el de la primera relación sexual fue de 11 a 15 años, con 55,8\%. El método anticonceptivo más utilizado fue la esterilización femenina, representada por $29,5 \%$. El comportamiento homosexual se encontró en $17,9 \%$. Los datos todavía mostraron un alto número de embarazos y abortos. Llegamos a la conclusión de que estas mujeres necesitan más atención de los profesionales de salud y de acciones de salud que son específicos para el contexto penitenciario, pues tienen riesgos ginecológico y obstétrico.

DESCRIPTORES: Prisiones. Características de la población. Mujeres. Enfermería. 


\section{INTRODUCTION}

The prison system is considered to be a worldwide public health problem since it brings together a population, which is especially vulnerable to infectious diseases. ${ }^{1}$

In Brazil, the imprisoned population's health condition is even more concerning. Urban violence increases every day, associated with the increase of the prison population; however, prison capacity remains the same, causing overpopulation and thus favoring various pathologies.

Therefore, this group requires greater attention to their health. According to the Organic Health Law No 8080, healthcare provided to the population must occur through health promotion, protection and recovery interventions, in addition to preventive and care delivery actions. It is also necessary to maintain health care equality, without prejudice or privilege, including the prison population. $^{2}$

Given the great need for health interventions among the prison population, the Federal Government created the National Health Plan in the Prison System (PNSSP, as per its acronym in Portuguese) in 2003, with the objective to organize access to care in male, female and psychiatric units of the Unified Health System (SUS, as per its acronym in Portuguese). Healthcare must be comprehensive and organized in the prison unit through primary healthcare strategies and services provided by interdisciplinary health teams. ${ }^{3}$

Among PNSSP goals, the importance of implementing preventive actions for preventing hepatitis, sexually transmitted diseases (STDs/ AIDS) and the distribution of condoms are highlighted. ${ }^{3}$

These actions have become very relevant to the female population, since most illnesses resulting from STDs occur in women. ${ }^{4}$ In addition; the current scenario demonstrates an increase in the number of AIDS and STD cases within this group.

Many factors contribute to this susceptibility: biological characteristics, inequalities between men and women, the lack of opportunity to talk about sexuality and learn about one's body, difficulties in negotiating protected sexual relations, lack of use of condoms, socioeconomic and cultural conditions that may limit access to services and a lack of appropriate interventions and information focused on the prevention of STDs. ${ }^{5}$

Thus, actions of the multidisciplinary team in prisons must be specific, mainly in guiding their actions in order to promote efficient and necessary interventions to meet the needs of this population group. Moreover, understanding the individuals requiring care is fundamental for planning strategic actions and evaluating the impact of these professionals as health providers for this population group.

Therefore, the following questioning emerged: what are the sexual and reproductive characteristics prevalent in imprisoned females?

Thus, in accordance with PNSSP, emphasizing the need for performing broad national studies that will reveal this population's epidemiologic profile, this present study is relevant as it enables the identification of the sexual and reproductive characteristics of these women in order to implement health promotion policies congruent with this group's reality. Therefore, this present study had the objective to identify the gynecologicobstetric profile of imprisoned women in the state of Ceará.

\section{METHODOLOGY}

This is a documental, retrospective and quantitative study performed in the Female Prison Institute of the State of Ceará. The institution has the capacity to hold 300 women and is the only penitentiary in the State, therefore it is responsible for all women who break the law and were or will be judged in the state of Ceará. ${ }^{6}$

The penitentiary facility is undergoing a restructuring process in order to meet the mandates of the PNSSP. The healthcare team is comprised of a nurse, a general practitioner, two nursing technicians one pediatrician, one gynecologist, one dentist, one dental assistant, one social worker, and a psychologist. Regarding goals established by the PNSSP for maintenance of women's health, the institution has appointments available to the women for the screening/prevention of cervical and uterine cancer, pre-natal visits, and the distribution of male condoms and female contraceptive devices.

The study utilized the populations' completed institutional medical files for all appointments granted from 2003 to 2010 . This period was chosen due to the creation of the PNSSP by the Ministry of Health in 2003, resulting in the beginning of the restructuring of prison units with a view to meeting the established guidelines.

Inclusion criteria were medical files specifically referencing gynecology appointments. Exclu- 
sion criteria were: prenatal medical files, since they had no relevant information for the objective of the study; and those medical files dated prior to 2003.

A total of 2,322 medical files were analyzed. Of these, 1,650 were excluded due to the aforementioned exclusion criteria, comprising a final sample of 672 medical files. Variables of the study present differing values for $n$, due to the absence of completed records in the medical files, resulting in a constant difficulty in locating the applicable documents.

Data collection occurred throughout June and July of 2010, by searching information in the available medical files and utilizing a structured instrument based on the institution's medical files.

The data collection instrument included information regarding sociodemographic characteristics and data from gynecology appointments (main complaint, age of menarche, age of commencement of sexual activity, sexual behavior, contraceptive methods, pregnancies, deliveries, types of delivery and abortions).

Data were filed and analyzed using the Statistical Package for Social Sciences for Personal Computer (SPSS-PC), version 17.0, and is presented in tables; the frequency of findings were calculated and discussed according to the pertinent literature.

Ethical aspects regarding research involving human beings were respected according to Resolution 196/96, and a statement numbered 229/09 by the Research Ethics Committee of the Federal University of Ceará was issued.

\section{RESULTS AND DISCUSSION}

Results analysis was based on 672 medical files from women who attended a gynecology appointment in the prison facility.

Quantitative data corresponding to age were analyzed according to the median and the interquartile intervals, due to the fact that the variables followed an abnormal distribution. Thus, the median age was 29 years with a minimum of 18 and maximum of 65 years, with an interquartile interval of 12 years.

Youngsters were observed to participate more frequently in illegal acts. Commonly included in the population with a lower income bracket, often unemployed with poor future prospects, they become the targets of criminals and are subjected to violence, drug use and a broken family structure. These facts increase the statistical prevalence of illegal acts committed by the people included in this age bracket. ${ }^{1}$

Table 1 - Distribution of inmates according to sociodemographic characteristics. Aquiraz-CE, 2010

\begin{tabular}{lrr}
\hline Variables & $\mathbf{f}$ & \multicolumn{1}{c}{$\%$} \\
\hline Age bracket (n=609) & 191 & 31.4 \\
18-24 years & 188 & 30.9 \\
25-31 years & 121 & 19.9 \\
32-38 years & 63 & 10.3 \\
39-45 years & 46 & 7.6 \\
46 years or more & & \\
Education ( $\mathbf{n}=\mathbf{1 4 1 )}$ & 7 & 5.0 \\
Illiterate & 82 & 58.2 \\
Incomplete primary education & 24 & 17.0 \\
Complete primary education & 4 & 2.8 \\
Incomplete secondary education & 19 & 13.5 \\
Complete secondary education & 5 & 3.5 \\
Higher education. & & \\
Marital status (n=268) & 209 & 78.0 \\
Single & 31 & 11.6 \\
Married & 17 & 6.3 \\
Stable union & 6 & 2.2 \\
Widowed & 5 & 1.9 \\
Divorced & & \\
Occupation (n=266) & 156 & 58.6 \\
General services/maid & 47 & 17.6 \\
Merchant and sales & 36 & 13.5 \\
Other occupations & 15 & 5.6 \\
Student & 12 & 4.5 \\
Seamstress & & \\
Nationality (n=261) & 33 & 12.64 \\
Brazilian & & \\
Other &
\end{tabular}

Also, an increase in the involvement of women in criminal events is observed, consequently raising the female prison population. Therefore, describing the unique characteristics of imprisoned women is prudent in order to create health promotion strategies congruent with the reality of the group in this study.

Regarding education, this study demonstrated a low level of education, since $63.2 \%$ (89) of the participants had failed to complete a primary education and 5\% (7) were illiterate.

These data corroborate a study performed with 287 imprisoned females in Porto Alegre. The study demonstrated a similar index of women with an incomplete primary education (63.1\%). ${ }^{7}$ In 
a penitentiary in the State of São Paulo, the average number of years of education observed was 5.9 years \pm 2.9 , and the median was five years. ${ }^{8}$

This present study demonstrates a fact that is in accordance with other research involving imprisoned women: $77.3 \%$ (85) of the inmates are single. In São Paulo, a study performed with 358 inmates demonstrated that $52 \%$ of the females were single. ${ }^{8}$

A relationship between marital status and the type of crime committed was demonstrated. Generally, women who were married or in a stable union were arrested due to their relationships, either due to drug trafficking or domestic violence. Single women are, more often, imprisoned due to drug use/trafficking and property crimes. ${ }^{9}$

A research with 955 women at the Rio de Janeiro penitentiary, performed for the purpose to characterize the sociodemographic profile, the criminal history, use of drugs, and the presence of STDs in imprisoned women, found that the women were an average of 31 years of age. Moreover, that study also identified a prevalence of women who had only a primary education, either incomplete or complete (72.6\%) (90), and $54.4 \%$ (68) reported being single, corroborating the findings in this present research. ${ }^{1}$

Occupation was characterized as being low social/economic status occupations in half of the women. This population's poor education may explain the elevated number of women with low income employment.

A research performed in São Paulo, which corroborates this present study, had the objective to determine the mental health profile of 358 imprisoned women. It demonstrated that most women in the penitentiary come from less favored levels of society, a fact that can be explained by the low level of education and the predominance of low qualification occupations with proportionally low salaries. ${ }^{8}$

The nationality of the inmates demonstrated that although most women were Brazilian, there were a significant number $(12.64 \%)$ of women from other countries (33), mainly from the African continent, representing $66.6 \%$ (22) of the foreign women. Most of these foreign women were involved in international drug trafficking.

The large number of women imprisoned due to drug trafficking results from the submissive position these women occupy in the drug traffic structure, giving them fewer opportunities to negotiate with the police to obtain their freedom. There has been an important growth in the number of foreign women imprisoned for this reason, from $1 \%$ in 1976 to $11 \%$ in 1997 , due to the increase in the international drug traffic, a fact that is congruent with the findings of this present study. ${ }^{10}$

Data related to the imprisoned women's sexual history are presented in table 2.

Table 2 - Distribution of the inmates according to their gynecologic history and sexual orientation characteristics. Aquiraz-CE, 2010

\begin{tabular}{lrr}
\hline Variables & $\mathbf{f}$ & \% \\
\hline Menarche $(\mathbf{n}=\mathbf{5 6 3 )}$ & & \\
Less than 10 years & 36 & 6.4 \\
10 to 13 years & 322 & 57.2 \\
14 to 17 years & 198 & 35.2 \\
Older than 17 & 7 & 1.2 \\
Age of first sexual encounter debut & & \\
( $\mathbf{n = 1 6 3 )}$ & & \\
Less than 11 years & 20 & 3.6 \\
11 to 15 years & 314 & 55.8 \\
16 to 20 years & 212 & 37.7 \\
21 to 25 years & 14 & 2.5 \\
Sexual orientation $(\mathbf{n = 3 5 2 )}$ & & \\
Homosexual & 63 & 17.9 \\
Heterosexual & 268 & 76.1 \\
Bisexual & 21 & 6 \\
\hline
\end{tabular}

Data regarding menarche agreed with research that aimed at investigating the age of menarche in developed and developing countries, which found that the first menstrual period is happening much earlier than in the past including in Brazil. ${ }^{11}$

Menarche is the main physical marker of sexual maturity. Lower age at menarche is a common trend in many populations, including the Brazilian population. It may be related to improved socioeconomic conditions that have occurred in the past few decades. ${ }^{12}$

In addition to earlier menarche, teenagers have become sexually active younger than in the past. This is clear when the age of first sexual intercourse is analyzed, which was between 11 and 15 years in $55.8 \%$ (314) of the inmates in this present study.

A study performed with 48 imprisoned women in Goiás, Brazil demonstrated that the age of first sexual experience occurs between the ages of 12 and 17 years, since $91.1 \%$ of the women reported having sexual partners at a 
young age, in agreement with the findings from this present study. ${ }^{13}$

Data presented demonstrated very high percentages of early first sexual encounters, especially when compared to data from a research regarding knowledge, attitudes and practices related to STD and AIDS in the Brazilian population aged 15 to 64 years, performed by the Ministry of Health in $2008 .{ }^{14}$ According to that research, only $17 \%$ of sexually active women between 15 and 64 years had their first sexual encounter before 15 years of age; on the contrary, this present study demonstrated $71 \%(45.8 \%)$ of the women had their first sexual encounter before 15 years of age.

This early beginning of sexual activity demonstrates that family planning and sexual and reproductive health promotion must occur intensively in the adolescent period, since it can be a determining factor in the gynecologic health of these young women. ${ }^{15}$ Moreover, early education also provides an opportunity to educate young women (and young men) about STD prevention. STDs have been increasing among the young population, mainly among those who experiment with sexual intercourse at a young age.

Sexual orientation was examined in a research performed in the female penitentiary in São Paulo. The study, which included 655 women, found that $98.3 \%$ reported having heterosexual habits and $1.7 \%$ reported being homosexual. The author states these numbers must be carefully analyzed, since the low number of women claiming to be homosexual can be related to fear or embarrassment of revealing sexual orientation due to prejudice and/or discrimination. ${ }^{16}$

However, the absence of partners is constantly mentioned as being a hardship while imprisoned. Up until recently, only one female penitentiary in Rio de Janeiro allowed private visitation. Lack of affection and inability to engage in sexual intercourse are factors that make being imprisoned harder to bear, creating an environment in which affection and sexual involvement among inmates occurs. This problem was also found in the institution in this study, since private visitation occurs every two weeks in a small room with one bathroom allocated specifically for private visitations.

Most women experienced homosexual relationships while in prison. ${ }^{9}$ However, some inmates reported already identifying as being homosexual before being imprisoned. Some authors state that "intern homosexuality" is a frequent occurrence due to seclusion and that it is used as a coping as a way to preserve affection. ${ }^{18}$

Homosexual relationships among inmates create a high-risk situation for STDs, since most people believe that sexual practices between women do not confer a risk of infection with such diseases. Therefore, health professionals in prison settings must always guide the women using educational strategies to promote safe sexual practices, independent of sexual orientation. In addition, for effective STD/AIDS prevention it is important to make the individual aware of his/ her vulnerabilities. ${ }^{19}$

Analysis of the contraceptive methods used by the inmates is presented in Table 3 . It shows that $31.7 \%$ (90) of women do not use contraceptive devices. This high number may be related to the fact that most women are single.

Table 3 - Distribution of the inmates according to contraceptive methods. Aquiraz-CE, 2010

\begin{tabular}{lcc}
\hline Contraceptive method $\mathbf{( n = 2 8 1 )}$ & $\mathbf{f}$ & $\mathbf{\%}$ \\
\hline None & 90 & 31.7 \\
Tubal ligation & 86 & 30.3 \\
Oral contraceptives & 63 & 22.2 \\
Male condoms & 29 & 10.2 \\
Injectable contraceptives & 12 & 4.2 \\
IUD & 3 & 1.1 \\
Female condoms & 1 & 0.4 \\
\hline
\end{tabular}

Among married women and women in a stable union, there are a low number who receive private visitors. Imprisoned men are three times more likely to receive private visitors than imprisoned women. ${ }^{1}$ Hence, although women may have partners, they have no private visitors and do not use any contraceptive method.

A high percentage of women had undergone tubal ligation, a concerning situation since the group is mostly comprised of young women at the most fertile period of their reproductive life. Studies point out that the younger a patient undergoes a tubal ligation, the higher the risk of later regret. ${ }^{20-22}$ Thus, quality family planning is necessary, including education regarding all contraceptive methods and their advantages and disadvantages in order to allow women to choose the method that will bring more benefits than risks.

Male condoms were mentioned in a study performed in a female penitentiary in the city of Cariacica (metropolitan region of Vitória) with 
121 women, in which $78.5 \%$ of the women stated they had never or rarely used condoms, either as a contraceptive method or for STD prevention. ${ }^{23}$

The female condom was used by only $0.4 \%$ (1) of inmates. Similar findings were demonstrated in a research that evaluated the use of female condoms by sexually active men and women from 16 to 65 years, where only $3.5 \%$ of women mentioned using it once in their lifetime, confirming that this method is unpopular and, among female condom users, only a small number use this barrier method for protection against STDs and pregnancy. ${ }^{24}$ The need for educational strategies is needed in order to guide the appropriate use of this method.

Reasons for gynecological exams in this study included vaginal discharge in $24.9 \%$ (197), followed by women seeking a routine Pap test (14.2\%) (112); other complaints included strong odor, vulvar itching, dyspareunia and dysuria.

A study with the objective of identifying the sociodemographic profile and health conditions of imprisoned women in a female penitentiary in the state of Espirito Santo demonstrated data with higher numbers than this present study, indicating that $44.9 \%$ of gynecology complaints involved leucorrhea (vaginal discharge) and pelvic pain $(35.6 \%){ }^{23}$

Table 4 demonstrates the obstetric history data of the women in this study.

Table 4 - Distribution of inmates according to obstetric variables. Aquiraz-CE, 2010

\begin{tabular}{lrr}
\hline Variables & f & \% \\
\hline Pregnancies $(\mathbf{n = 5 0 6 )}$ & 174 & 34.4 \\
1 to 2 & 178 & 35.2 \\
3 to 4 & 154 & 30.4 \\
5 or more pregnancies & & \\
Deliveries ( $\mathbf{n}=\mathbf{4 8 0 )}$ & 217 & 45.2 \\
1 to 2 deliveries & 170 & 35.4 \\
3 to 4 deliveries & 61 & 12.7 \\
5 to 6 deliveries & 32 & 6.7 \\
7 or more deliveries & & \\
Abortions/Miscarriages $(\mathbf{n = 5 7 0 )}$ & 322 & 56.5 \\
None & 138 & 24.2 \\
1 & 96 & 16.8 \\
2 to 3 & 6 & 1.1 \\
4 to 5 & 8 & 1.4 \\
6 or more abortions & & \\
Vaginal birth ( $=\mathbf{4 3 8 )}$ & 114 & 26.0 \\
None & 82 & 18.7 \\
1 & 147 & 33.6 \\
\hline to 3
\end{tabular}

\begin{tabular}{lrr}
\hline Variables & f & \multicolumn{1}{c}{$\%$} \\
\hline 4 to 5 & 60 & 13.7 \\
6 or more & 35 & 8.0 \\
C-sections $(\mathbf{n = 4 0 9 )}$ & & \\
None & 235 & 57.5 \\
1 & 104 & 25.4 \\
2 to 3 & 63 & 15.4 \\
4 to 5 & 5 & 1.2 \\
6 or more & 2 & 0.5 \\
\hline Total & $\mathbf{4 0 9}$ & $\mathbf{1 0 0 . 0}$ \\
\hline
\end{tabular}

The median number of pregnancies was 3 $(\mathrm{IQ}=4)$; the minimum was one and the maximum number of pregnancies was 22 .

Data demonstrate a high birth rate in the women in this study when compared to the findings in the last national study regarding Demographics and health, which demonstrated a decreasing number of pregnancies. The birth rate of northeastern women decreased from 3.1 children to 1.8 children per women between 1996 and 2006..$^{25}$

However, a study performed with 81 prostitutes demonstrated an elevated birth rate, in which $46 \%$ (36) of the women had been pregnant three to four times and $11.8 \%$ (7) had been pregnant more than seven times, data that is congruent with this present study. ${ }^{26}$ Thus, less favored social classes may present a high number of pregnancies, demonstrating the need for more efficient family planning strategies that will guide these women in choosing a contraceptive method that is most appropriate for their reality.

Despite the number of vaginal deliveries being higher than the number of C-sections, as shown in table 4, Brazil is considered one of the countries that has an overly high rate of this type of delivery. This is concerning, since one of the indicators evaluating the quality of obstetric care is the rate of C-sections performed in the country; when this rate is high the country becomes a target for debates and criticism. ${ }^{13}$

The most common reason for performing a C-section are: tubal ligation and women's and doctors' inadequate knowledge and lack of preparation for natural childbirth. Many doctors believe that women prefer $\mathrm{C}$-sections and heed requests for $\mathrm{C}$-sections even when vaginal childbirth is appropriate. C-sections have become so common that natural childbirth has lost its status as a routine practice, even when a preference for natural childbirth is stated. ${ }^{27}$ 
Research comparing adolescent and adult expectations regarding delivery and knowledge about the indications for C-section concluded that natural childbirth was the most anticipated type of delivery $(74.7 \%)$; however, this expectation decreased among those who had a previous C-section. The main justification for preferring natural childbirth was a faster recovery, while the reasons for choosing a $\mathrm{C}$-section were concerns about the pain of childbirth and complications for the newborn, among other reasons. ${ }^{28}$

Forceps use in delivery was experienced by $1.9 \%$ (6) of the imprisoned women. Congruent with this present study, a research performed with 151 pregnant women demonstrated that only one patient had experienced a delivery aided by forceps. ${ }^{29}$ The number of deliveries involving the use of forceps is diminishing over time.

Analysis of abortion in this population demonstrated that $43.6 \%$ (248) of the women had had at least one abortion. The number of women in this study who had at least one abortion is extremely high, but this number is similar to another study performed with 121 inmates that demonstrated that $50.4 \%$ (61) of women had a past history of abortion. $^{22}$

There are already several studies that demonstrate that abortion practices are associated with socioeconomic factors, difficult relationships with partners, lack of family support and age, among others. ${ }^{30}$ Given the findings previously demonstrated, most of the population observed in this study presents risk factors associated with abortion practices. Thus, the need for further studies to determine the true reasons for the elevated abortion rates among women in this study is demonstrated, in addition to the need for educational actions and the guarantee of access to contraceptive devices that must be prioritized for these specific demographic groups.

\section{CONCLUSION}

The gynecologic-obstetric profile of inmates demonstrated a population comprised of young, poorly educated and socially and economically disadvantaged women who have experienced early onset of sexual activity and high rates of pregnancies and abortions.

Knowing this population profile is extremely important for identifying the main vulnerabilities of the group so that health recovery, promotion and protection strategies are congruent with the reality experienced by these women.

The absence of relevant information in the medical files in this study was a limitation. The importance of quality health records indicating the health actions undertaken is highlighted, since these documents contain important information for the development of future studies towards the improvement of health care.

From analysis of the data in this study, there is a great need for health actions and interventions in the female prison population, as this population is frequently forgotten in their imprisonment. Due to high-risk behaviors, this population has a great need for education on and prevention strategies.

Although public policies that include the imprisoned population as health care subjects exist, human and financial resources to reach the goals proposed by PNSSP are not a high priority

Given the above information, the activities of health professionals become important, mainly for nurses engaged in health education focusing on sexual and reproductive health promotion for these women.

Undoubtedly, the health care trajectory is difficult, since prejudice must be overcome. However, the profile analysis demonstrated in this present research is expected to enable the development of new researches with these clients, with a view to improving health care in this group and guiding interventions to meet the unique and special needs of this population.

\section{REFERENCES}

1. Carvalho AL, Valente JG, Assis SG, Vasconcelos AGG. Perfil dos internos no sistema prisional do Rio de Janeiro: especificidades de gênero no processo de exclusão social. Ciencia Saúde Coletiva. 2006 AbrJun; 11(2):461-71.

2. Ministério da Saúde (BR), Secretaria Especial de Políticas para as Mulheres. Plano Nacional de Política para Mulheres. Brasília (DF): MS; 2004.

3. Ministério da Saúde (BR), Departamento de Ações Programáticas Estratégicas. Plano Nacional de Saúde no Sistema Penitenciário. Série B. Textos Básicos de Saúde. 2ed. Brasília (DF): Editora do Ministério da Saúde. 2005.

4. Guedes TG, Moura ERF, Paula NA, Oliveira NC, Vieira RPR. Mulheres monogâmicas e suas percepções quanto à vulnerabilidade a DST/HIV/ aids. DST. J Bras Doenças Sex Transm. 2009 Ago; 21(3):118-23. 
5. Ministério da Saúde (BR). Plano Integrado de enfrentamento a feminização da epidemia de Aids e outras DST. Brasília (DF): MS; 2007.

6. Secretaria de Justiça e cidadania do estado do Ceará (SEJUS). Ceará (CE); 2008 [atualizado 2008 Out 07; acesso 2010 Mai 15]. Disponível em: http://www.sejus.ce.gov.br/index.php/gestaopenintenciaria/39/69 2008

7. Canazaro D, Argimon IIL. Características, sintomas depressivos e fatores associados em mulheres encarceradas no Estado do Rio Grande do Sul, Brasil. Cad Saúde Pública [on line]. 2010 Jul [acesso 2011 Jul 13]; 26(7):1323-33. Disponível em: http:/ / www. scielo.br/scielo.php?script=sci_arttext\&pid=S010211X2010000700011\&lng=en

8. Moraes PAC, Dalgalarrondo P. Mulheres encarceradas em São Paulo: saúde mental e religiosidade. J Bras Psiquiatr. 2006 Mar; 55(1):50-6.

9. Guedes MA. Intervenções psicossociais no sistema carcerário feminino. Psicol Cienc Prof. 2006 Dez; 26(4):558-69.

10. Lemgruber J. Cemitério dos vivos: análise sociológica de uma prisão de mulheres. $2^{\mathrm{a}}$ ed. Rio de Janeiro (RJ): Forense; 1999.

11. Carvalho WRG, Farias ES, Guerra-Júnior G. A idade da menarca está diminuindo? Rev Paul Pediatr. 2007 Mar; 25(1):76-81.

12. Grandim CV, Ferreira MBL, Moraes, MJ. O perfil das grávidas adolescentes em uma unidade de saúde da família de Minas Gerais. Rev APS. 2010 Jan-Mar; 13(1):55-61.

13. Araújo RC. Agência Goiana do Sistema Prisional: estudo das condições sociodemográficas e comportamentais de mulheres de detentos, relacionadas à vulnerabilidade ao vírus HIV [dissertação]. Goias (GO): Universidade Católica de Goiás, Programa de Pós Graduação em Ciências Ambientais e Saúde; 2006.

14. Ministério da Saúde (BR), Instituto Nacional do Câncer (INCA). Coordenação de Prevenção e Vigilância. Estimativas de incidência e mortalidade por câncer no Brasil [página da internet]. Rio de Janeiro (RJ): INCA: 2008. [acesso 2008 Set 26]. Disponível em: http://www.inca.gov.brasil.br/ estimativas/2008

15. Nicolau AIO, Moraes MLC, Lima DJM, Aquino PS, Pinheiro AKB. Laqueadura tubária: caracterização de usuárias laqueadas de um serviço público. Rev Esc Enferm USP [online]. 2011 Mar [acesso 2011 Mai 25]; 45(1). Disponível em: http://www.scielo.br/ pdf/reeusp/v45n1/08.pdf

16. Lima M. Da visita íntima à intimidade da visita: a mulher no sistema prisional. [Dissertação]. São Paulo (SP): Universidade de São Paulo. Departamento de Saúde Materno-Infantil; 2006.
17. Santos MBS, Néri HF, Oliveira MFL, Quitete B, Sabroza A. Do outro lado dos muros: a criminalidade feminina. Mnemosine. 2009 Jul-Dez; 5(2):174-88.

18. Assis SG, Constantino P. Filhas do mundo: infração juvenil no Rio de Janeiro. Rio de Janeiro (RJ): Fiocruz; 2001.

19. Aquino OS, Nicolau AIO, Moura ERF, Pinheiro AKB. Perfil sociodemográfico e comportamento sexual de prostitutas de Fortaleza-CE. Texto Contexto Enferm. [online]. 2008 Jul-Set [acesso 2011 Jul 21]; 17(3):427-34. Disponível em: http:/ / www. scielo.br/scielo.php?script=sci_arttext\&pid=S010407072008000300003\&lng $=$ en\&nrm $=$ iso

20. Hardy E, Bahamondes L, Osis MJ, Costa RG, Faundes A. Risk factors for tubal sterilization regret, detectable before surgery. Contraception. 1996 Set; 54(3): 159-62.

21. Vieira EM. O arrependimento após a esterilização cirúrgica e o uso das tecnologias reprodutivas. Rev Bras Ginecol Obstet. 2007 Mai; 29(5):225-9.

22. Pacagnella RC. Ocorrência de disfunção sexual entre mulheres submetidas à laqueadura tubária no município de Ribeirão Preto [dissertação]. Ribeirão Preto (SP): Universidade de São Paulo. Faculdade de Medicina de Ribeirão Preto; 2007.

23. Miranda AE, Merçon-de-Vargas PR, Viana MC. Saúde sexual e reprodutiva em penitenciária feminina, Espírito Santo, Brasil. Rev Saúde Publica. 2004 Abr; 38(2):255-60.

24. Barbosa, RM, Perpetuo I. Análise das estratégias de prevenção da disseminação do HIV entre mulheres no Brasil, especialmente do uso do preservativo feminino. Documento preliminar produzido no âmbito do Termo de Referência do UNFPA - Contrato de consultoria \# 042/2009. Nov 2009 [acesso 2010 Set 20]. Disponível em: http://nepaids.vitis.uspnet.usp.br/wp-content/ uploads/2010/04/capitulo-CF-Regina-Barbosalivro-UNFPA-SPDM1.pdf

25. Sociedade Civil Bem-Estar Familiar no Brasil, Programa de Pesquisas de Demografia e Saúde, Macro Internacional. PNDS-2006: cai a taxa de fecundidade no Nordeste. Brasília (DF): Agencia Saúde/Demografia e Saúde. [acesso 2010 Set 20]. Disponível em: http:/ / portal.saude.gov.br/portal/ arquivos/pdf/pndsnordeste.pdf

26. Nicolau AIO, Aquino OS, Moura ERF, Pinheiro AKB. Perfil gineco-obstétrico e realização do exame de prevenção por prostitutas de Fortaleza. Rev RENE. 2008 Jan-Mar; 9(1):103-10.

27. Campana HCR, PellosoSM. Levantamento dos partos cesárea realizados em um hospital universitário. Rev Eletr Enf [online]. 2010 Abr [acesso 2011 Mar 15]; 9(1):51-63. Disponível em: http:/ / www.fen.ufg.br/ revista/v9/n1/v9n1a04.htm 
28. Bruzadeli DS, Tavares BB. Expectation about childbirth type and the knowledge of the caesarean reason: comparison between puerpera adolescent and adult. Rev Eletr Enf [online]. 2010 Mar [acesso em 2011 Mar 25]; 12(1):150-7. Disponível em: http:/ / www.fen.ufg.br/revista/v12/n1/v12n1a18.htm

29. Franzin, CMMO, Silva JLP, Pereira BG, Marba STM, Morais SS, Amaral T, Reszka EB. Centralização de fluxo sanguíneo fetal: comparação entre os índices diagnósticos. Rev Bras Ginecol Obstet. 2010 Jan; 32(1):11-8.

30. Oliveira MS, Oliveira ICFJ, Fernandes AFC. Razões e sentimentos de mulheres que vivenciaram a prática do aborto. Rev RENE. 2005 Set-Dez; 6(3):23-30.

E-mail: samilaribeiro@yahoo.com.br 